\title{
THE EFFECT OF CLUSTERING TECHNIQUE ON STUDENTS' WRITING ABILITY
}

\author{
Sumartini \\ Universitas Bengkulu, \\ Sumartinihdm13@gmail.com \\ Hilda Puspita \\ Universitas Bengkulu, \\ Puspitahilda@gmail.com \\ Zahrida \\ Universitas Bengkulu \\ Zahrida@yahoo.com
}

\begin{abstract}
The research was aimed to investigate whether clustering technique can affect students' writing ability. The research was conducted at the first year students of Senior High School number 8 Bengkulu. In conducting the research, the researcher applied a quasi experiment method with MIA 2 and MIA 1 as the sample. MIA 2 as an experimental group that consist of 24 students was taught by using clustering technique and MIA 1 as a control group that consist of 26 . They were taught by conventional technique. Both of the groups were given pre-test at the beginning, the post test at the end of the treatment. The data were analyzed by using t-test formula. From the culculation, the reseacher found that t-count was 2.07 and t-table was 2.01. For T-count of organization was 2.56, t-count of content was 3.62 and t-count of coherent was 3.47. Since t-count was higher that t-table, it means $\mathrm{H}_{1}$ was accepted. So, it can be concluded that clustering technique affects students' writing ability. In spesific, clustering technique improved students' content, organization, and coherent text.
\end{abstract}

Keywords: Writing, Clustering Technique

\section{INTRODUCTION}

Writing is one of the four skills that is very essential for learning a second language such as English. Raimes (1983) states that writing is one of skill that is important for students because of some reasons. First, writing makes students strong in grammatical structure, idioms, and vocabulary. Second, writing makes students apply the language they have learned. Third, writing strengthens students to express their ideas in correct words and sentences. Therefore, students need to be involved in writing.

In the Indonesian curiculum of Senior High School, writing is one of the English skills that should be mastered by students of Senior High School. It also included in the national examination so that students of Senior High School should be able to write some of text types such as descriptive, narrative, recount and so on.

However, there are many students considered writing as a difficult skill to learn. Bram in Khoiriyah (2014) states that 
for beginning writers, expressing what they intend is usually difficult. Difficulties such as finding the idea, developing the idea, choosing the vocabulary, and organizing the idea also happened. Furthermore, grammar and also the use of mechanic of writing such as the use of capital letter, comma, or punctuation are also made it more difficult.

The problems also happened to the first year students of Senior High School number 8 Bengkulu in the academic year 2017. The results of observation that the reseacher conducted on 31 November until 3 December when she did the third internship at Senior High School number 8 Bengkulu, she found that most of them have problems in finding and also developing the idea. Futhermore, the average of students' writing score was only 63. Then, it appears a question what is an effective way to teach writing in order to make them easy to learn.

In order to make them easy to learn, teachers need to implement a suitable technique. According to Buscemi (2002) clustering is a technique that helped the students to find and develop ideas. Lagan (2005) stated that clustering technique can gather the importent ideas in students' mind. It also improves students' independent in writing and it is also adaptable for all ages of students.

Moreover, there were some related studies which have been done by reseachers that proved clustering technique can improve students' writing ability. For example, a study in one Senior High School in Bandung showed that clustering technique was effective in improving student's score in writing narrative text (Andrianti, 2013). Sugiarti (2012) proved that clustering technique was effectively improving the students' writing ability at the Eighth Grade of MTs Raudlatul Ulum. Another study also showed that the implementation of clustering technique could improve student' writing ability of grade VIII-2 of SMPN 2 Tarumajaya Bekasi (Salam, 2011).

Therefore in order to solve the problem mentioned, the reseacher conducted a research at the first grade students of Senior High School number 8 Bengkulu entittled "The Effect of Clustering Technique on Students' Writing Ability". In this reseach, the reseacher was continuing the study of clustering technique in order to find out whether or not clustering technique had a significant effect on the students' writing ability. In spesific, the questions were formulated as follow:

1. Is there a significant effect of the use of clustering technique on students' writing ability in composing content?

2. Is there a significant effect of the use of clustering technique on students' writing ability in composing text organization?

3. Is there a significant effect of the use of clustering technique on students' writing ability in composing the coherent of text?

\section{Clustering Technique}

1. Definition of Clustring Technique

Clustering technique is pre-writing activity used by writers to produce ideas in diagramming or mapping form. It is introduced by a professor of English and Creativity at San Jose State University named Gabriele Lusser Rico in 1980s. Rico difined clustering technique as the way of tricking the left brain into silence and using the right to come up with your own technique overview of a subject in order to produce ideas.

According to Oshima and Hogue (2007) clustering technique is another brainstorming activity that can use to generate ideas. According to Gary Tate 
(1976) clustering technique is a visual way to look at your ideas and relate them to each other. Smalley and Mary stated (2000) that clastering technique is a visual map of ideas. It is the same like mind mapping, listing ideas but the differece is clustering technique more generative, open-ended, non-linear, visual structuring of ideas, events, and feelings..

Another expert said that clustering technique is an invention activity reveals possible relations among facts and ideas. Unlike other pre-writing activities, clustering technique requires a brief priod of initial planning that should liniar so that much consuming time.

Based on the definition above, the writer summarize that clustering technique is an activity to make a visual map or new associations that allows the user thinking more creatively and to begin without clear ideas.

\section{The Application of Clustering} Technique in Writing

In order to cluster, the first that the writer should do is write the topict in the blank sheet of paper and draw a circle around it. Then, draw lines away from the topic. At the end of each line, write idea that comes to your mind and draw a circle around it. Continue to draw the lines, write ideas and draw circled as much as possible to write.

This is example of clustering technique with "holiday in summer" topic. If you were writing a text with holiday in summer, the first you can write the word "summer in Hong Kong" in the center of the page if you are holiday in Hong Kong. After that, using others lines, circles and arrows, writes ideas, feelings, objects or actions that related with the topic such as food, activities, weather and others. Then, continue to draw the lines, write ideas such as salad, ice cream, mangoes, watermelons, and draw circled as much as possible.

The result looks like this following chart:

Figure 1 Clustering Technique

(Curriculum Development Institute, 2004)

3. The Adventages of Using Clustering Techniquep

In writing process, there are some adventages of using clustering technique. First is clustering technique can stimulus students' ideas. It means that this technique helps the students' produces ideas as much as possible.

Second, clustering technique guides the students to compose the ideas into good composition of writing. It will make the students have good product of writing that easy to understand by reader.

Third, clustering technique makes students think more creative and motivate the students to write because it guide the students in writing and also make the students focus on their thought as much as possible. Furthermore, it makes the sudents are not bored in composing writing text.

The forth, clustering technique is adaptable for all ages of students. In others word, clustering technique an be used by everyone in pre-writing stages and all of english level such as intermediate, advance even beginner.

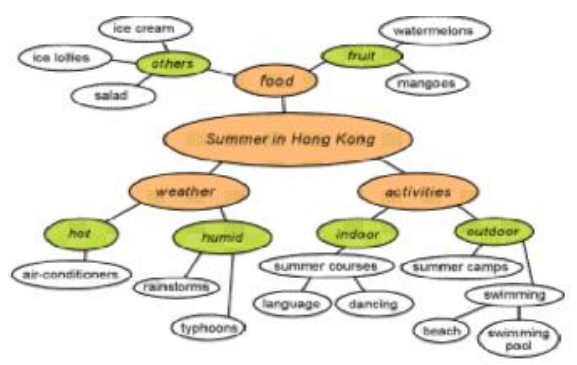


The five, clustering can be used for any kind of writing text. It uses in the beginning of writing in order to plan writing or in order to find topic to organize information. Writer also can use clustering to plan brief section of text as they are drafting.

\section{METHODO}

The design of this research was a quasi experimental which means that there were two groups. The first group was experimental group which will be taught by applying clustering technique and the second group was control group which was taught by applying conventional technique. The groups were given pre-test and also post-test. The results of the pretest score and post-test score were used to find out whether clustering technique had a significant effect on the students' writing ability.

The design of this research can be drawn as following chart :

Experimental group : Y1....X1......X2
Control group $\quad:$ Y1...XX $0 . . . . X 2$

$$
\begin{aligned}
& \mathrm{Y} 1=\text { Pre test } \\
& X 2=\text { Post test } \\
& X 1=\text { Experimental treatment } \\
& X 0=\text { Convetional method }
\end{aligned}
$$

The population of this reseach was the first year students of Senior High School number 8 Bengkulu and the sample of this research were MIA 1 students and MIA 2 students. MIA 2 students was one group which will be chosen as the experimental group. While MIA 1 students was chosen as control group.
In order to find out the writing achievement of the students, the researcher used a writing test as the primary instrument. The test was writing descriptive text of an actress biography. This test was adapted from Zahara (2014) and in order to score the students' work the researcher was using Heaton's scoring technique (1988).

In analyzing the data which were obtaned from the pre-test and post-test, the reseacher used this following formula:

$$
t=\frac{\bar{X}_{1}-\bar{X}_{2}}{S_{\text {diff }}}
$$

$$
\begin{aligned}
& S_{\text {diff }} \\
& =\sqrt{\frac{\sum X_{1}^{2}-\frac{\left(\sum X_{1}\right)^{2}}{n_{1}}+\sum X_{2}^{2}-\frac{\left(\sum X_{2}\right)^{2}}{n_{2}}}{n_{1}+n_{2}-2}\left[\frac{1}{n_{1}}\right.} \\
& \left.+\frac{1}{n_{2}}\right]
\end{aligned}
$$

Where :

$$
\begin{aligned}
& t=\text { Coefficient of significant } \\
& \Sigma=\text { Total score } \\
& X_{1}=\text { Mean score of experiment group } \\
& X_{2}=\text { Mean score of control group } \\
& \Sigma X_{1}=\text { Total score of experiment group } \\
& \Sigma X_{2}=\text { Total score of control group } \\
& n_{1}=\text { Total sample of experiment group } \\
& n_{2}=\text { Total sample of control group } \\
& \text { (Arikunto, 2006) }
\end{aligned}
$$

\section{RESULT AND DISCUSSION}

The pre-test was conducted on Monday 20 February 2017 for experimental group and Saturday 25 February 2017 for control group. From the caculation of the pre-test 
result score, the pre-test result can be seen in the following chart:

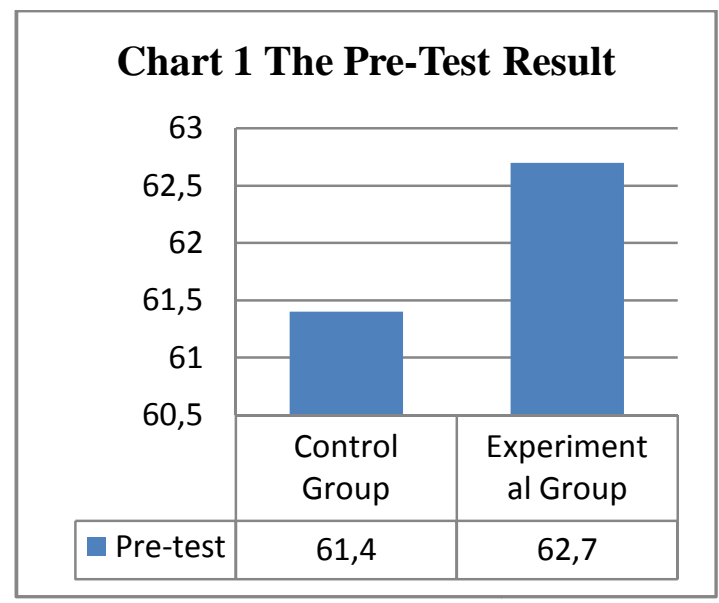

The chart above show that the mean score of experimental group was 62.7 and the mean score of control group was 61.4. It means the result of students' writing score was not much different. For the pretest result of each aspects of writing, it can be seen in the following table:

Table 3 The Pre-Test Result

\begin{tabular}{|l|l|l|l|}
\hline No & Aspect & $\begin{array}{l}\text { The } \\
\text { mean } \\
\text { score of } \\
\text { control } \\
\text { group }\end{array}$ & $\begin{array}{l}\text { The } \\
\text { mean } \\
\text { score of } \\
\text { experim } \\
\text { ental } \\
\text { group }\end{array}$ \\
\hline 1 & Content & 57.5 & 57.39 \\
\hline 2 & $\begin{array}{l}\text { Organizati } \\
\text { on }\end{array}$ & 67.21 & 68.75 \\
\hline 3 & Coherent & 61.63 & 62.29 \\
\hline
\end{tabular}

The table show that the mean of content score of experimental group was 57.39 and the mean score of control group was 57.5. The mean of organization score of experimental group was 68.75 and the mean score of control group was 67.21. The mean of coherent score of experimental group was 62.29 and the mean score of control group was 61.63. It means that the mean score of experimental group and also control group was not much different. In other words, both of experimental group and control group had equal ability. This means that the experiment could be continuing.

The post-test of experimental group was conducted on Monday 20 March 2017 and to the control group, it was conducted on Saturday 25 March 2017. From the caculation of the pre-test result score, the post-test result of students' writing score can be seen in the following chart:

\section{Chart 2 The Post-Test Result}

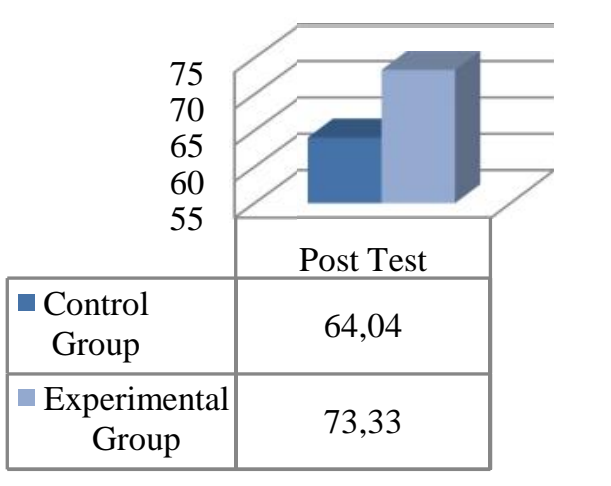

The chart show that the mean score of control group was 64.04 while the mean score of experimental group was 73.33. It show that the mean score of the two groups was much different which was 9.29. This means there is a significant different in students' writing score between control group and experimental group. For the post-test result of each aspects of wring can be seen in the following Table:

Table 4 The Post-Test Result

\begin{tabular}{|l|l|l|l|}
\hline No & Aspect & $\begin{array}{l}\text { The mean } \\
\text { score of } \\
\text { control } \\
\text { group }\end{array}$ & $\begin{array}{l}\text { The } \\
\text { mean } \\
\text { score } \\
\text { of }\end{array}$ \\
\hline
\end{tabular}




\begin{tabular}{|l|l|c|c|}
\hline & & & $\begin{array}{l}\text { experi } \\
\text { mental } \\
\text { group }\end{array}$ \\
\hline 1 & Content & 62.31 & 70.10 \\
\hline 2 & $\begin{array}{l}\text { Organizat } \\
\text { ion }\end{array}$ & 68.85 & 79.06 \\
\hline 3 & Coherent & 61.63 & 71.15 \\
\hline
\end{tabular}

The table show that the mean of content score of control group was 62.31 and the mean score of experimental group was 70.10. The mean of organization score of control group was 68.85 and the mean score of experimental group was 76.06. The mean of coherent score of control group was 61.63 and the mean score of experimental group was 71.15. It shows that the mean score of experimental group and also control group was much different.

From the calculation of the posttest result score by using t-test in students' writing score, it was found that T-count was 2.07 and T-table was 2.01. It showed that the t-count was bigger than T-table $(2.07>2.01)$. This means $\mathrm{H}_{1}$ was accepted and $\mathrm{H}_{0}$ was rejected. For $\mathrm{T}$-count and T-table of each aspects of wring can be seen in the following table:

Table 5 T-Count of Each Aspects of Writing

\begin{tabular}{|c|c|c|}
\hline Aspect & T-Table & T-Count \\
\hline Content & 2.01 & 3.62 \\
\hline Organization & 2.01 & 2.56 \\
\hline Coherent & 2.01 & 3.47 \\
\hline
\end{tabular}

From the table above T-table was 2.01. T-count of Content Score was 3.62. T-count of organization was 2.56 and Tcount of coherent was 3.47. It shows that the T-count of the three aspects of writing was bigger than T-table. It means $\mathrm{H}_{1}$ was accepted and $\mathrm{H}_{0}$ was rejected.
In conclusion of the calculation of the post-test result score by using t-test, $\mathrm{H}_{1}$ was accepted and $\mathrm{H}_{0}$ was rejected. In other word, there was a significant difference in score between experimental group and control group. This means that the use of clustering technique could improve students' writing skill achievement.

\section{The Analysis of Pre-Test and Post Test Result of Writing Score}

In order to find out whether the treatment gave positive effect or not, the analysis was done by comparing the score of experimental group and also control group by using T-test. The result showed that there was a significant different in score between the experimental group and control group. In order to clarify the result, it can be seen in following chart:

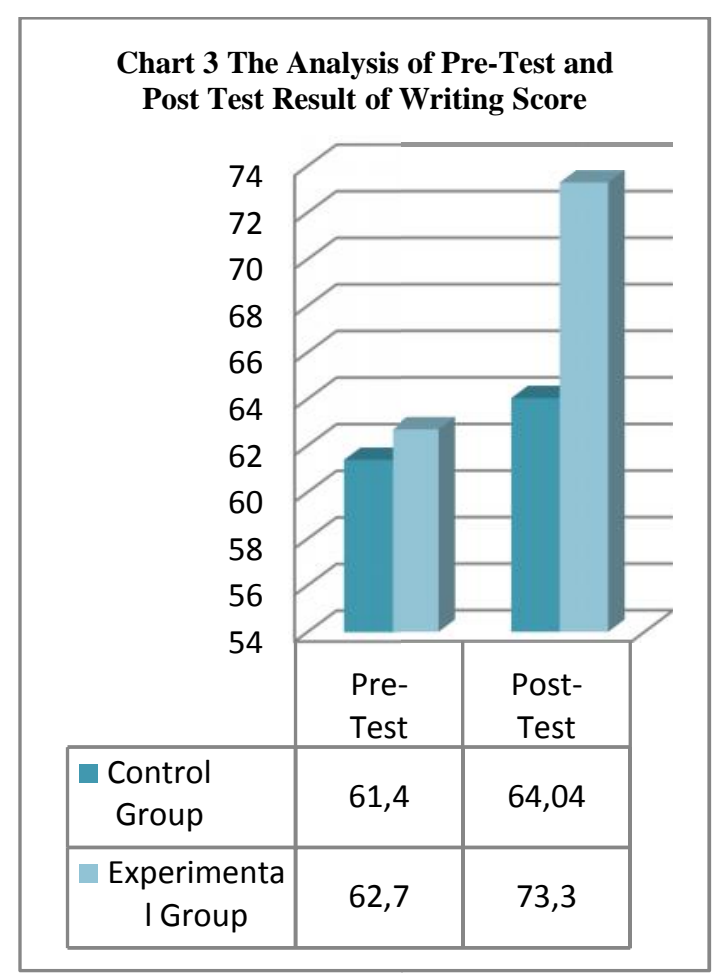

The chart show that the mean score of control group in pre-test was 61.4 and the mean score of experimental group was 62.7. While the mean score of control group in post-test was 64.04 and the 
mean score of experimental group was 73.3. The different score of pre-test and post-test in control group was only 3.36 while the different score of pre-test and post-test in experimental group was much different which was 10.6. This means there was a significant different in score between the experimental group and control group.

\section{Discussion}

This section is the analysis part of result or research finding based on the theories related to the study. Based on previous explanation of test result, the finding of this research was there was a significant difference in score between experimental group and control group.This means that clustering technique was an effective way to improve students writing ability. It prove the theory of Gabriele Lusser Rico (1980) and also in line with the three previous studies that conducted by Adrianti (2013), Sugiarti (2012), and Salam (2011) that confirmed the clustering technique could improve students' writing ability. In specific, the technique could improve the three aspects of writing as follow:

\section{Content}

Using clustering technique could improve students' content score. In other words, by using clustering technique, the students became to know what to write. As when the reseacher gave them a topic of embarassing moment in life in order to write recount text, the students directly wrote the topic on the middle of page. Then, the students were helped and stimulated by clustering technique to find out creative ideas by adding all things that were related to the topic. The students easily followed the ideas that gave them information what to write. This condition proved the statement of Buscemi (2002) who said clustering help students to find ideas.

Furthermore by using clustering technique, the students were easy to get ideas. It proved the theory of Oshima and Hogue (2007) that stated clustering technique can use to generate ideas. Beside that as a visual map of ideas (Smalley and Ruetten, 2000) by using clustering technique, the students did not forget ideas that they want to write. Moreover clustering technique allowed the students thinking creatively and associatedly.

In contrast, the students' who were taught by conventional technique were still difficult to find ideas to write. They did not know what to write. Even when the reseacher divided them into group of four in order to brainstorming ideas, only some students were active. Most of the students followed other students' ideas.

\section{Organization}

By using clustering technique, the students knew how to write text or to organize the text. There were many texts that should be mastered by students which have different organization. This made most students became confused to write the text organizingly. For example, when the researcher gave the students task about writing recount text, the students were confused to provide information about the orientation, events and also the reorientation. By using clustering technique, the students clearly understand in providing the information into the organization. the students easily divided among the orientation, events and also the reorientation by clustering the information about them. 
In contrast, the students' who were taught by conventional technique were still confused how to provide all organization that should be provided in writing a text. The students also doubted how to start the writing.

This finding confirmed the finding of the three previous studies that conducted by Adrianti (2013), Sugiarti (2012), and Salam (2011) that could improve the students' writing achievement that also considered organization as an aspect that had the highest score.

\section{Coherent}

By using clustering technique, the students' writing result became more coherent. It was caused by using clustering technique, the students just wrote information that was related to the topic. It made the students easy to relate one sentence to another. Clustering technique also made students classified the ideas into the organization so that it made the students easier to relate from one idea into another. As a result, the writing products of students who used clustering technique were more coherent than the students who did not use clustering technique.

In contrast, the students who were taught by conventional technique started to write the text in bahasa Indonesia then translated it into English. It made the writing products were uncoherent. As a result most of their writing products were still difficult to understand. Therefore the students who were taught by conventional technique could not increase their achievement greatly as the students who were taught by using clustering technique.
This finding proved the theory of Gary Tate (1976) who said that clustering technique is a visual way to look at your ideas and relate them to each other. Therefore, it could make the coherent score of the students who were taught by clustering techniqe increase.

\section{CONCLUSION AND SUGGESTION}

Based on analysis and finding in this study, it can be concluded as follow:

There is a significant effect of the use of clustering technique on students' writing ability at the first year students of Senior High School number 8 Bengkulu in the academic year 2017. In specific,

1. There is a significant effect of the use of clustering technique on students' writing ability in composing content. It can be seen from the students' writing score that showed the students' score who taught by clustering technique that helped students in gathering ideas were higher that students' score who taught by conventional technique.

2. There is a significant effect of the use of clustering technique on students' writing ability in composing text organization. It also can be seen from the students' writing score that showed the students' score who taught by clustering technique that helped students by clustering the information into text organization were higher that students' score who taught by conventional technique.

3. There is a significant effect of the use of clustering technique on students' writing ability in composing the coherent of text. This effect can be seen from the students' writing score that showed the students' score who 
taught by clustering technique that helped students by providing information that related to the topic were higher that students' score who taught by conventional technique.

Based on the conclusion above, it was suggested as follow:

1. For the teachers

Teacher should use pre-writing activity while teaching writing. Clustering technique in teaching writing is one of pre-writing activity that can be an alternative for the teacher. ClusteriPng technique help the teacher to teach a text organizingly and motivate the students greatly.

2. For Students

In composing a writing, students can use clustering technique as prewriting activity to help them in finding the ideas, developing ideas, and so on. Beside that, they also have to enrich their vocabulary in order to make them

3. For Further Reseacher

This study was conducted in limited time and limited population. Therefore, further researcher can conduct in a larger population and longer time. Furthermore this study is also limited only on content, organization and coherent. Therefore, further researcher also can conduct on the other aspects of writing.

\section{REFERENCES}

Arikunto, S. (2006). Prosedur Penelitian, Sixth Edition. Jakarta: PT Rineka Cipta.

Adriati, M. (2013). The Use of Clustering Technique in Teaching Writing Narrative Text. (Thesis:
Indonesia University of Education, 2013)

Buscemi, S.V.(2002). A reader for Developing Writers. New York: McGraw Hill Company.

Khoiriyah. (2014). Increasing the students' writing skill through mind mapping technique.

Nusantara of reasearch, 1(2), 177187.

Langan, John. (2005). College Writing Skills, New York: McGraw Hill.

Oshima, A and Ann Hogue. (2007). Introduction to Academic Writing, Third Edition. Harlow: Longman.

Rico, Lusser, Gabrielle "Pre-Writing: Clustering",from:

http://exchanges.state.gov/forum/jo urnal, January 16, 2016.

Raimes, A. (1983). Technique in Teaching Writing. New York: Oxford University Press.

Salam, A. (2011). Using Clustering Technique to Improve Students' Writing of Recount Text. (Thesis: Syarif Hidayatullah State Islamic University, 2011)

Smalley, R.L. and Mary K.R .(2000). Refining Composition Skill. New York: Imnternational Tompson Publishing Company, $5^{\text {th }}$ edition.

Sugiarti, D. W. (2012). The Effectiveness of Clustering Technique in Teaching Writing at The Eighth Grade of MTs Raudlatul Ulum. (Thesis: Institute of Islamic Studies Sunan Ampel, 2012)

Tate, Gary. (1976) Teaching Composition: 10 Bibliographical essays, Texas: Texas Christian University Press.

Zahara, S. (2014). The Effectiveness of Teaching DescriptiveTtext Using Picture Mediaon Students 
Ability (Thesis: SyarifHidayatullah

State Islamic University, 2014) 